\title{
Potential of Lime on Modified Lateritic Soil Using Locust Bean Waste Ash as Admixture
}

\author{
Nwadiogbu, P.C. ${ }^{1^{*}}$, Salahdeen, A.B. ${ }^{2}$ \\ ${ }^{1}$ Department of Civil Engineering, Federal Polytechnic Kaura Namoda, Zamfara State. \\ ${ }^{2}$ College of Agriculture, DAC., Ahmadu Bello University, Zaria
}

\begin{abstract}
An A-7-6 (11) lateritic soil using AASHTO soil classification system, collected from Shika area of Zaria, Nigeria, was treated with up to $4 \%$ lime and up to $8 \%$ locust bean waste ash (LBWA) by dry weight of the soil. The sieve analysis of the modified soil was carried out immediately after mixing (i.e., 0 hour elapse time). The results of sieve analysis indicate an increase in the particle sizes (i.e., reduction in the fines fraction) with increase in lime/LBWA content. Improvement in the Atterberg limits was also observed. The maximum dry density (MDD) for British Standard Light (BSL) compaction increased to a peak value at $4 \%$ LBWA for all lime contents. For the West African Standard (WAS) compaction, the MDD follows the trend of continuous decrease, while no consistent trend was observed for the British Standard Heavy (BSH) compaction. The corresponding optimum moisture content $(O M C)$ values for all the three compactive efforts generally increased steadily. Cohesion generally decreased, while the corresponding angles of internal friction increased with increase in lime/LBWA content.
\end{abstract}

Keywords: lateritic soil, locust bean waste ash, Lime, modification, cohesion

\section{Introduction}

Laterites have been given many definitions and because of various views from researchers, this generated a lot of controversies that lasted for over a hundred and fifty years, until Alexander and Cady (1962) came up with the definition that was believed to gain a wide acceptance. Laterite was defined as highly weathered material rich in secondary oxides of iron or aluminium or both. It is nearly of bases and primary silicates, but it may contain large amount of quartz and kaolinite. It is either hard or capable of hardening on exposure to wetting and drying. Laterite is a highly weathered tropical soil, rich in secondary oxides of any or a combination of iron, aluminium and manganese. In some cases they contain swelling clay mineral types (e.g., vermiculite, hydrated halloysite and montmorillonite) in which case they are known as problematic lateritic soils (Osula, 1984).

Laterites are used as road making material and they form the sub-grade of most tropical roads; they are used as sub-base and base for low cost roads and these carry low to medium traffic. A lot of lateritic gravels and pisoliths are good for gravel roads. There are instances where laterites may contain substantial amount of clay minerals that its strength and stability cannot be guaranteed under load, especially in the presence of moisture. These laterites are also common in many tropical regions including Nigeria where in most cases sourcing for alternative soil may prove economically unwise but rather improve the available soil to meet the desired specification (Osinubi and Bajeh, 1994; Mustapha, 2005).

Nigeria, like any other country of the world is a producer of waste from various sources such as human, biological, agricultural, industrial, etc, but poor management practice of these waste leads to severe soil and groundwater contamination as well as adverse health effect. Locust bean waste ash is one of such waste being generated. Several researchers (Mohammedbhai and Baguant, 1990; Osinubi, 1995; 1998, 1999; Cokca, 2001; Medjo and Riskowiski, 2004) have worked to obtain cheaper additives that can be used to substitute the expensive industrially manufactured soil improving additives (cement, lime, bitumen etc). This led to the consideration of agricultural waste resources such as rice husk ash (RHA), bagasse ash (BA) locust bean waste ash (LBWA), etc.

The locust bean tree is common in our environment and it grows to about $15 \mathrm{~m}$ in height with dark, evergreen, pinnate leaves. The small, red flowers have no petals. The fruit is slightly curved indehiscent pod of $30-40 \mathrm{~cm}$ long and $2-3 \mathrm{~cm}$ wide. They are leathery, hang in clusters by the club-shaped fruit base, and are dry and brown in colour when ripe. Each pod contains many seeds, which are embedded in sweet, yellow, floury pulp. The seeds are brown blackish. Each seed has a $0.5-1 \mathrm{~cm}$ long funicle, it is globular-ovoid and slightly compressed laterally. The testa is hard, smooth and glossy. The waste products of these edible seeds pollute our environment. Once the seed is used for local food seasoning, the waste (i.e. husk or pod) from it when burnt produces the locust bean waste ash (LBWA). LBWA is a pozzolana that is capable of reacting with lime in the presence of water at ordinary temperature to produce a cementitious compound which could act as a partial replacement or substitute to other pozzolanas (Akinmade, 2008). 
The use of lime for stabilization dates back to early times. Its principal use is in highway construction and maintenance, airfields construction, building foundation, rail road beds and under hydraulic conditions where the soil is partly or wholly submerged (e.g., irrigation canals, reservoirs, levees and dams). Lime stabilization has been used successfully on many projects to minimize swelling and improve soil plasticity and workability. Generally, from 3 to $8 \%$ hydrated lime by weight of dry soil is added to the top several inches of the soil. It is also used as a follow-up treatment over ponded area to add strength to the surface, provide a working table for equipment and prevent evaporation by capillary rise from the treated layer below (McDowell, 1965; Teng et al., 1973).

\section{Materials}

\section{Materials And Methods}

The lateritic soil sample used for this study was obtained by method of disturbed sampling from a borrow pit in Shika area of Zaria (Latitude $11^{\circ} 15^{\prime} \mathrm{N}$ and Longitude $7^{\circ} 45^{\prime} \mathrm{E}$ ). The lime used in this study is hydrated lime with typical assay of 95 to $97 \%$ calcium hydroxide and was obtained from National Research Institute for Chemical Technology (NARICT), Zaria. The locust bean waste ash (LBWA) used for the study was obtained locally from burning of locust bean husks sourced from villages dumps and stockpiled. The stockpiled husks were burnt to ash in the open air at temperature in the range $500-700{ }^{\circ} \mathrm{C}$. The locust bean waste ash (LBWA) was sieved through B.S. sieve No. 200 before usage. The oxide composition of the lime and locust bean waste ash (LBWA) was carried out at Centre for Energy Research and Training (CERT), Ahmadu Bello University, Zaria using the method of Energy Dispersive X-ray Fluorescence (EDXRF) and the results of the tests are shown in Table 1.

\section{Methods}

Laboratory tests were performed to determine the index properties of the natural soil samples in accordance with BS 1377 (1990) and lime/LBWA treated lateritic soil samples in accordance with BS 1924 (1990). The compaction tests were carried out for the natural and modified soils (in 0-4\% of lime and 0-8\% of LBWA by dry weight of soil.); using the British Standard light (BSL) energy, in accordance with the Nigerian General Specifications (1997). The strength characteristic test performed in this study is the undrained triaxial compression test which was carried out at OMC and MDD.

Soil Identification

\section{Results And Discussion}

The results of the identification test conducted on the natural soil are summarized in table 2 .

Table 1: Oxide composition of the hydrated lime and locust bean waste ash

\begin{tabular}{lcc}
\multicolumn{1}{c}{ Oxide Composition } & \multicolumn{2}{c}{ Concentration (\%) } \\
\cline { 2 - 3 } & Hydrated lime & Locust bean waste ash \\
$\mathrm{CaO}$ & 44.73 & 1.78 \\
$\mathrm{SiO}_{2}$ & 37.91 & 57.21 \\
$\mathrm{Al}_{2} \mathrm{O}_{3}$ & 11.67 & 11.75 \\
$\mathrm{Fe}_{2} \mathrm{O}_{3}$ & 0.19 & 5.01 \\
$\mathrm{MgO}$ & - & 11.39 \\
$\mathrm{SO}_{3}$ & - & - \\
$\mathrm{MnO}_{n}$ & 0.11 & 0.58 \\
$\mathrm{Na}_{2} \mathrm{O}$ & - & 0.013 \\
$\mathrm{~K}_{2} \mathrm{O}$ & - & 1.03 \\
$\mathrm{P}_{2} \mathrm{O}_{5}$ & - & - \\
\hline $\mathrm{Loss}$ on Ignition & - & 10.13 \\
\hline
\end{tabular}

\section{Effect of Lime/LBWA on Atterberg Limits}

The variations of Atterberg limits with soil-lime/LBWA mixes are shown in Figures 1 to 3. The liquid limit and plasticity index decreased with addition of admixtures. This decrease can be associated with the agglomeration and flocculation of the soil particles which is as a result of exchange ions at the surface of the soil particles (Moses and Afolayan, 2011). An increase was however observed in the plastic limit (see Fig. 2) with increase in lime/LBWA content. This is probably due to the higher release rate of $\mathrm{Ca}^{++}, \mathrm{Si}^{++}$and $\mathrm{Al}^{+++}$cations with increased lime/LBWA usage (Ramzi et. al., 2001). 
Table 2: Properties of the natural soil

\begin{tabular}{|l|c|}
\hline Property & Quantity \\
\hline Percentage passing No. 200 B.S. sieve & 68.2 \\
Natural Moisture Content (\%) & 6.41 \\
Liquid Limit (\%) & 41.4 \\
Plastic Limit (\%) & 23.5 \\
Plasticity index (\%) & 17.5 \\
Linear Shrinkage (\%) & 5.76 \\
Group index & 11 \\
AASHTO Classification & A-7-6 \\
Maximum Dry Density $\left(\mathrm{Mg} / \mathrm{m}^{3}\right)$ & \\
British Standard light & 1.66 \\
West African Standard & 1.75 \\
British Standard heavy & 1.88 \\
Optimum Moisture content $(\%)$ & 17 \\
British Standard light & 14.5 \\
West African Standard & 12.7 \\
British Standard heavy & \\
Cohesion (kN/m $\left.{ }^{2}\right)$ & 110 \\
British Standard light & 160 \\
West African Standard & 200 \\
British Standard heavy & \\
Angle of Internal Friction $\left({ }^{\circ}\right)$ & 19.5 \\
British Standard light & 21.5 \\
West African Standard & 27 \\
British Standard heavy & 2.69 \\
Specific Gravity & Yellowish brown \\
Colour & \\
\hline
\end{tabular}

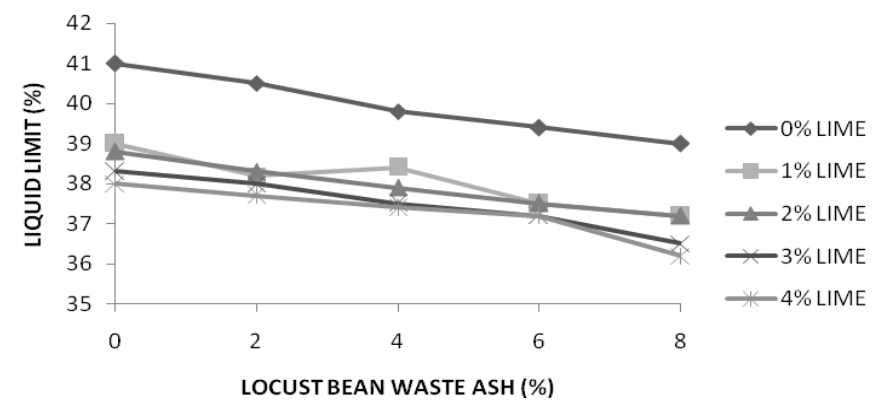

Figure 1: Variation of liquid limit of lateritic soil with lime/ LBWA content

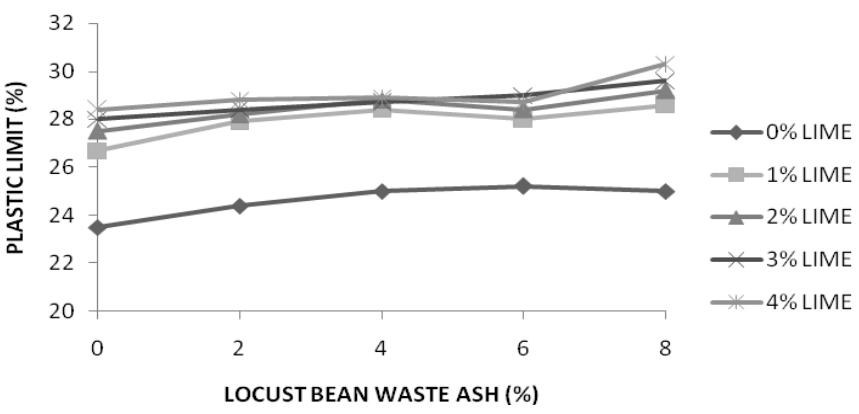

Figure 2: Variation of plastic limit of lateritic soil with lime/ LBWA content

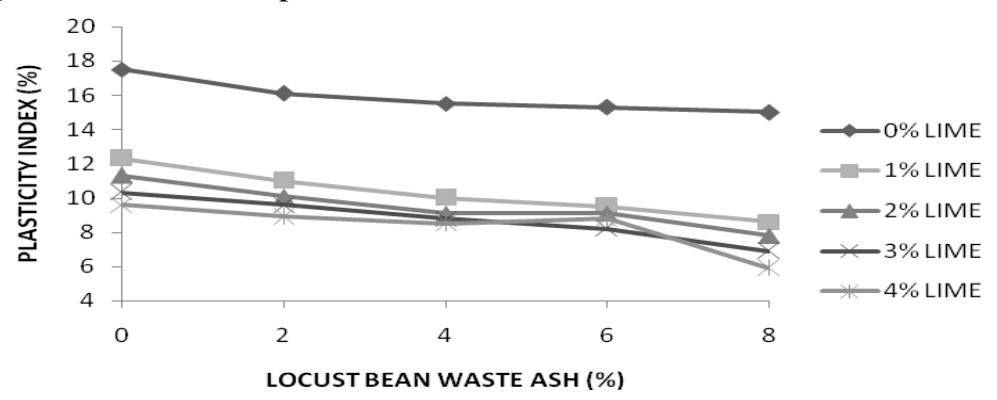

Figure 3: Variation of plasticity index of lateritic soil with lime/ LBWA content 


\section{Compaction Characteristics}

The variations of maximum dry density (MDD) and optimum moisture content (OMC) are shown in Figure 4 and 5 respectively. The MDD decreased while the OMC increased with increase in the lime/LBWA content. The decrease in the MDD (see Figure 4) can be attributed to the replacement of soil by the lime/LBWA in the mixture which has relatively lower specific gravity compared to that of the soil (Ola 1975; Osinubi and Katte 1997). The increase in OMC (see Figure 5) with increased lime/LBWA contents was due to the addition of lime/LBWA, which decreased the quantity of free silt and clay fractions and coarser materials with larger surface areas were formed (these processes need water to take place). This implies also that more water was needed in order to compact the soil-RHA mixtures (Osinubi 1999).

This trend is in line with Ola (1975), Gidigasu (1976), Iorliam et. al.(2012) and Osinubi (1999).

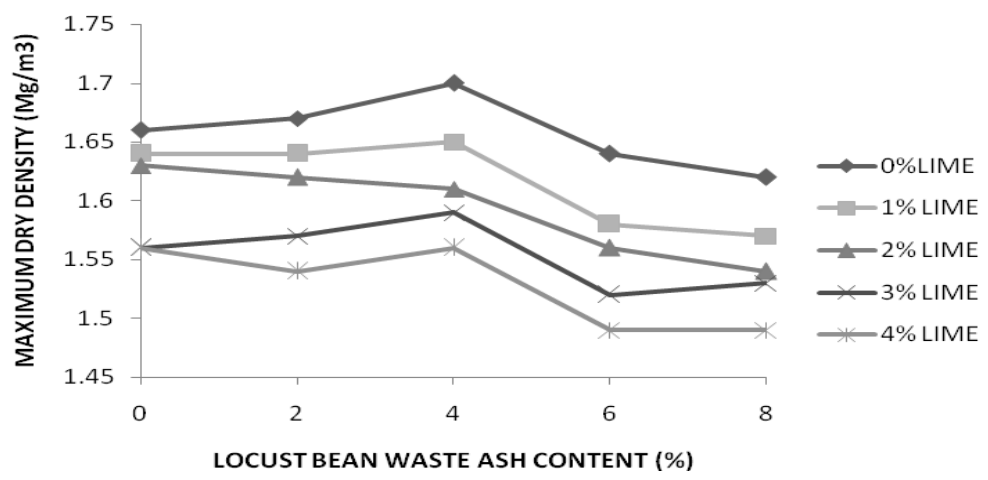

Figure 4: Variation of maximum dry density of lateritic soil with lime/ LBWA content

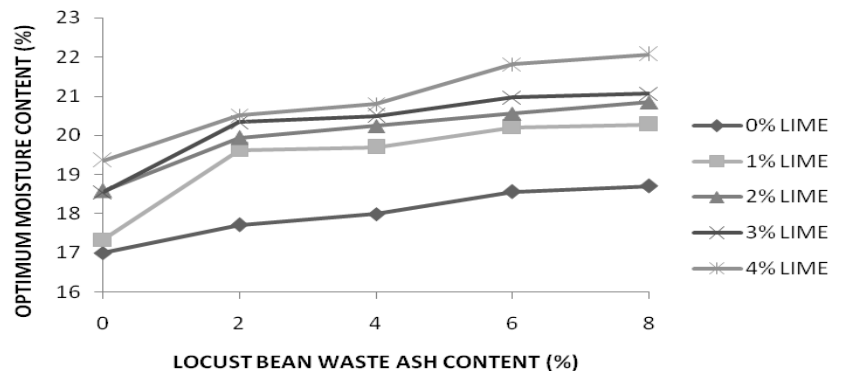

Figure 5: Variation of optimum moisture content of lateritic soil with lime/ LBWA content

\section{Shear Strength Characteristic}

The effect of lime/LBWA contents on the cohesion and angle of internal friction of the soillime/LBWA mixture are shown in Figures 6 and 7 respectively. The cohesion was observed to reduce with increased lime/LBWA contents. The angle of internal friction increased with increasing lime/LBWA contents, while the cohesion reduced. These are as a result of the reduction in clay size fractions due to the pozzolanic reaction (ion exchange reaction) between the lateritic soil and the $\mathrm{Ca}^{++}, \mathrm{Si}^{++}$and $\mathrm{Al}^{+++}$reach admixtures which resulted in larger perticles formation.

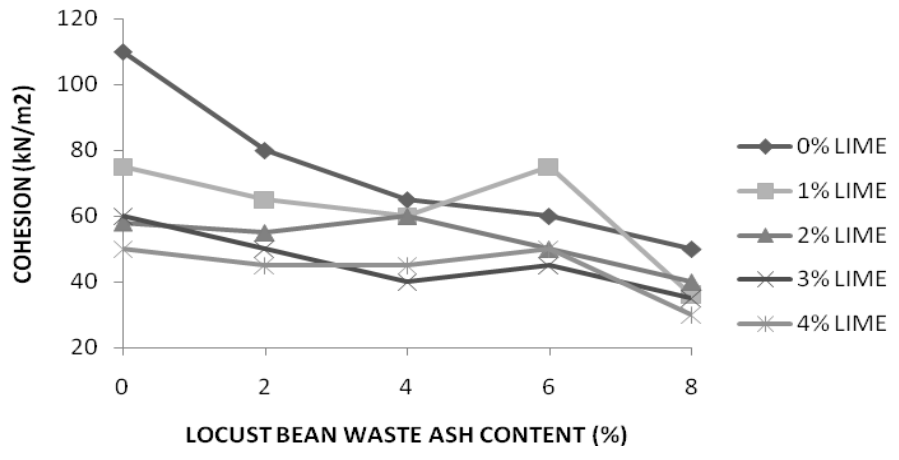

Figure 6: Variation of cohesion of lateritic soil with lime/ LBWA content 


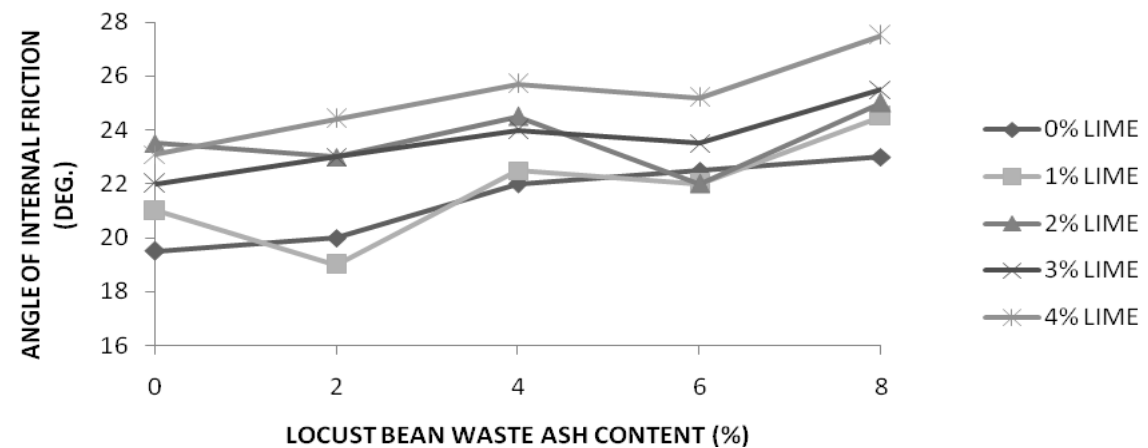

Figure 7: Variation of angle of internal friction of lateritic soil with lime/ LBWA content

\section{Conclusions}

Based on the results of the study conducted, the following are hereby concluded:

* The lateritic soil was classified as A-7-6 (11) using the AASHTO classification system.

* There was an improvement in the Atterberg limits of soil with all lime/LBWA treatments.

- Treatment with lime/LBWA shows a general decrease in the maximum dry density (MDD) and increase in optimum moisture content (OMC) of the lateritic soil with increase in lime/LBWA content .

* The cohesion of the soil drastically reduced while the angle of internal friction increased appreciably with lime/LBWA treatment.

* An optimal value of $2 \%$ lime/4\%LBWA is recommended for the modification of lateritic soil of class A-7-6 (11).

\section{References}

[1]. AASHTO (1986). "Standard Specification for Transportation, Material and Method of Sampling and Testing". 14th Edition. Amsterdam Association of State Highway and transportation official Washington D.C.

[2]. Akinmade O.B (2008). "Stabilization of Black Cotton Soil with Locust Bean Waste Ash". Unpublished M.Sc. thesis, Civil Engineering Department Ahmadu Bello University Zaria, Nigeria.

[3]. Alexander L.T. and Cady J.G (1962). "Genesis and Hardening of laterite soil.” U.S. Department of Agric, Technical Bulletin No. 1282 Washington DC USA, p.1-10

[4]. B.S. 1377 (1990). "Methods of Testing Soil for Civil Engineering Purposes". British Standards Institute, London.

[5]. B.S. 1924 (1990). "Methods of Tests for Stabilized Soils". British Standards Institute, London.

[6]. Cokca, E. (2001), "Use of class C fly ashes for stabilization of expansive soils." Journal of Geotechnical Engineering, Vol 127, No 7. pp $568-573$.

[7]. Gidigasu, M.D. (1976). "Laterite Soil Engineer-ing: Pedogenesis andEngineering Principles". Elsevier, Amsterdam, the Netherlands.

[8]. Iorliam, A.Y., Agbede,I.O. and Joel, M. (2012). "Effect Of Cement Kiln Dust On Some Geotechnical Properties Of Black Cotton Soil". EJGE. Vol. 17. pp.967-976.

[9]. McDowell, C. (1965). "Remedial procedures used in the reduction of detrimental effect of swelling soils." Engineering Effects of Moisture Changes in Soils. Concluding Proceedings, International Research and Engineering Conference on Expansive Clay Soils, Texas A \& M Univ. Press, College Station, TX pp 239-275

[10]. Medjo, E. and Riskowiski, G. (2004). “A Procedure for processing mixtures of soil, cement and sugar cane bagasse.” Agricultural Engineering International Journal of Scientific Research and Development. Manuscript BC 990, Vol. III, pp 1-6.

[11]. Mohammedbhai, G. T. G. and Bagant, B. T. (1990). "Possibility of using bagasse ash and other furnace residue as partial substitute for cement in Maritius." Revne Agricole et Sulclriere de l'lle Maurice, Vol. 64, No 3 pp.1-10.

[12]. Moses, G. and Afolayan, J.O. (2011). "Compacted foundry sand treated with cement kiln dust as hydraulic material" Electronic Journal of Geotechnical Engineering. Vol. 16, pp 337-355.

[13]. Mustapha M.A. (2005). Effect of Bagasse Ash on Cement Stabilized Laterite. Unpublished M. Sc. thesis Department of Civil Engineering, Ahmadu Bello University, Zaria.

[14]. Nigerian General Specifications (1997). Roads and Bridges. Federal Ministry of Works, Abuja, Nigeria.

[15]. Ola S.A. (1975). "Stabilization of Nigeria Laterite soil with cement, bitumen and lime." Sixth Regional Conference for Africa Soil Mechanic and Foundation Engineering Durban South Africa, p. 145-152.

[16]. Osinubi, K. J. (1995). "Lime modification of black cotton soils." Spectrum Journal, Vol. 2, Nos 1 and 2, pp. 112 - 122.

[17]. Osinubi, K. J. (1998). "Stabilization of tropical black clay with cement and pulverised coal bottom ash admixture." In: Advances in Unsaturated Geotechnics. Edited by Charles, D., Shackelford, Sandra L. Houston and Nien-Yin Cheng. ASCE Geotechnical Special Publication, No 99, pp 289-302.

[18]. Osinubi, K. J. (1999). "Evaluation of admixture stabilization of Nigerian black cotton soil." Nigerian Society of Engineers Technical Transactions, Vol. 34, No 3, pp 88-96.

[19]. Osinubi K.J. and Bajeh I. (1994) "Bituminous stabilization of laterite.” Spectrum Journal, Vol. 1, $\quad$ No. 2, pp. 104-112.

[20]. Osinubi, K.J. and Katte, V.Y. (1997). Effect of elapsed time after mixing on grain size and plasticity characteristics I: Soil- Cement mixes. NSE Technical Transaction, Vol. 32, No. 4, pp. 65-77.

[21]. Osula D.O.A. (1984). "Cement stabilization using hydrated lime as an admixture.”An Unpublished M.sc. Thesis Civil Engineering Department Ahmadu Bello University Zaria.

[22]. Ramzi, T., Amer, A., Ali, A. and Hilia A. (2001). "Use Of Cement Kiln Dust In Soil Stabilization”. EJUQ. Vol.14 pp.61-76.

[23]. Teng, T. C. P., Mattox, R. M., and Clisby, M. B. (1973). "Mississippi's experimental work on active clays." Proceedings of Workshops on Expansive Clays and shales in Highway Design and Construction, Univ. of Wyoming, Laramie, May 2, pp. 1-17. 